\title{
Dynamics of the movement of the ripping tool for surface tillage
}

\author{
Urol Abdurakhmonov", and Bakhodir Juraev \\ Karshi Engineering Economic Institute, Karshi, Uzbekistan
}

\begin{abstract}
The study aims to analyze the stability of the movement of the ripper tool for surface tillage. The basic principles and methods of classical mechanics, mathematical analysis, and statistics were used in this study. The dynamics of the movement of a ripper tool for surface tillage are considered, depending on the forces acting on it and its design parameters. A computational dynamic model is developed, and an equation describing the angular oscillations of the longitudinal links of the parallelogram ripper mechanism is obtained. It is established that the uniformity of the depth of the cultivator depends on the amplitude and frequency changes of the components of the disturbing force, physical and mechanical properties of the soil, the moment of inertia of the Ripper, the length of the longitudinal links parallelogram mechanism, the forces of the pre-tension pressure springs, and its stiffness. It is established that the required uniformity of the depth of tillage can be achieved by selecting the pre-tension force of the pressure spring and its rigidity. Theoretical and experimental studies have established that the required uniformity of the processing depth with minimal energy consumption of the soil is provided with a pre-tension force of the pressure spring of the ripper attachment mechanism of $350 \mathrm{n}$, spring stiffness of $40 \mathrm{n} / \mathrm{cm}$, and a speed of $2.0 \mathrm{~m} / \mathrm{s}$.
\end{abstract}

\section{Introduction}

In Uzbekistan, large-scale measures are being taken to develop resource-saving equipment and technologies with high efficiency [1-23], which reduce labor and energy costs, save resources in the cultivation of agricultural crops and ensure high-quality harvesting with the least losses [3, 10, 11, 19, 20].

Farmers and farmers are mostly engaged in the cultivation of vegetables, fruits and melons, and small plots. To increase the efficiency of their economy, they receive 2-3 harvests of these crops on the same plot during the year. Therefore, they till the soil in different periods of the year (spring, summer, autumn). This means that machines and tools for such farms should be highly maneuverable, easy to operate, light, and designed to work in different conditions.

In the conditions of cotton monoculture, wide-reach, large-sized machines, and tools with a powerful tracked tractor were developed for working in large farms and on large areas.

\footnotetext{
*Corresponding author: u.abdurahmonov64@mail.ru
} 
It is obvious that in the conditions of farms and peasant farms, tracked tractors are economically unprofitable due to their high cost, low utilization rate during the year, and even more so in small areas. This is also evidenced by the rich foreign experience where wheeled tractors are used everywhere in farms in all agricultural operations.

However, there are no-tillage machines for aggregating with wheeled tractors in production, and there have been practically no developments on them. Taking this into account, the Republic is currently actively conducting research and development projects aimed at creating a new generation of wheeled tractors of class 0.6-1.4 for farmers and peasant farms and a train of machines and tools for them.

One of the most important in the agrotechnical complex for preparing the soil for sowing crops is the surface treatment (harrowing) of fields. It is carried out to preserve moisture, destroy blocks, destroy sprouting weeds, level the field surface somewhat, and prevent the introduction of salts into the upper layers of the soil [31-32].

This work aims to develop a technological scheme and substantiate the main parameters of the tool for surface tillage for wheeled tractors of class 0.6-1.4.

\section{Methods}

The basic principles and methods of classical mechanics, mathematical analysis, and statistics were used in this study

Taking into account the above, we have developed a scheme and manufactured a tool for surface tillage. In the tool, two rippers are installed on one row. The ripper consists of two transverse bars (pipes) with teeth. It is installed on the hitch bar using two parallelogram mechanisms with pressure springs [35].

During the tool's operation, due to the variability of the physical and mechanical properties of the soil, the uneven micro-relief of the force fields $R_{x}, R_{z}$ Figure 1, acting on the ripper, continuously change. As a result, the balance of the ripper is constantly disturbed, and it makes angular fluctuations that lead to a change in the depth of tillage [36].

The calculated dynamic model of the ripper is shown in Figure 1. It consists of a frame 1 , a parallelogram hitching mechanism 2 , and a ripper $3[35,37,38]$.

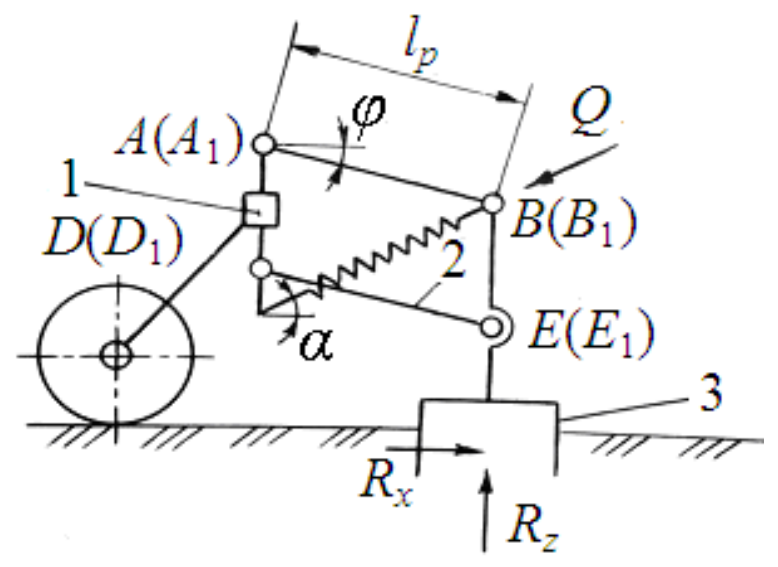

Fig. 1. Calculated dynamic model of the ripper

Assume that the longitudinal links $A B\left(A_{1} B_{1}\right)$ and $D E\left(D_{1} E_{1}\right)$ (links $A_{1} B_{1}$ and $D_{1} E_{1}$ are not shown in the figure) of the parallelogram mechanism are uniform and thin, at points $A\left(A_{1}\right)$ 
and $D\left(D_{1}\right)$ are pivotally attached to the frame, and at points $B\left(B_{1}\right)$ and $E\left(E_{1}\right)$ - with a ripper.

Figure 1 presents: $\ell_{n}$ is length longitudinal parts of the hitch mechanism; $R_{x}, R_{z}$ are horizontal and vertical components of force resistance of the soil; $\varphi$ is the angle of deflection of the longitudinal links from the equilibrium position; $Q$ is the pressure force of a pressure spring; $\alpha_{0}$ is the angle of the force vector $Q_{0}$ to the horizon.

We assume that: the movement of the Assembly in a straight line and at a constant speed; the impact of the frame on the cultivator slightly and theoretical calculations can be ignored; the deviation of the working body from the equilibrium position occurs in the range of small angles and increments the second and more degrees can be neglected; the equilibrium position of the longitudinal parts of the hitch mechanism horizontal.

\section{Results and Discussion}

We also assume that the vertical reaction $R_{z}$ soil cultivator is the sum of the elastic forces $F_{\mathrm{y}}$, linearly dependent on its vertical movement, the damping forces (viscosity) $R_{C}$, linearly dependent on the speed of vertical movement of the Ripper, and disturbing forces $\Delta R_{z}(t)$ arising from the variability of physico-mechanical properties of soil, i.e.

$$
R_{z}=F_{y}+R_{c}+\Delta R_{z}(t)
$$

The friction in the joints $A\left(A_{1}\right), B\left(B_{1}\right), D\left(D_{1}\right)$, and $E\left(E_{1}\right)$ is neglected due to their smallness.

For the generalized coordinate, we take the angle $\varphi$ of the deviation of the longitudinal links of the parallelogram mechanism from the horizontal.

Applying the differential equation of rotation of a rigid body around a fixed axis and taking into account the results of $[38,39]$, we obtain:

$$
\begin{aligned}
& J \frac{d^{2} \varphi}{d t^{2}}=-R_{x} \ell_{r} \sin \varphi+Q_{r} \ell_{r} \sin \varphi+\left[m_{r}+0,5\left(m_{v}+m_{n}\right)\right] x \\
& x g \ell_{p} \cos \varphi+Q_{v} \ell_{p} \cos \varphi-R_{z} \ell_{p} \cos \varphi
\end{aligned}
$$

or taking into account (1)

$$
\begin{aligned}
& J \frac{d^{2} \varphi}{d t^{2}}=-R_{x} \ell_{p} \sin \varphi+Q_{r} \ell_{p} \sin \varphi+\left[m_{r}+0,5\left(m_{v}+m_{n}\right)\right] x \\
& x g \ell_{p} \cos \varphi+Q_{v} \ell_{p} \cos \varphi-\left[F_{u}+R_{s}+\Delta R_{z}(t)\right] \ell_{p} \cos \varphi
\end{aligned}
$$

Since the angle $\varphi$ is quite small, then, gently $\sin \varphi \approx \varphi$ and $\cos \varphi \approx 1$, we get

$$
\begin{aligned}
& J \frac{d^{2} \varphi}{d t^{2}}=\left(Q_{r}-R_{x}\right) \ell_{p} \varphi+\left[m_{r}+0,5\left(m_{v}+m_{n}\right)\right]+g \ell_{p}+ \\
& +Q_{v} \ell_{p}-\left[F_{u}+R_{s}+\Delta R_{z}(t)\right] \ell_{p} \cos \varphi
\end{aligned}
$$

where $J$ is the moment of inertia of the ripper relative to the suspension axis; $m_{r}$ is the mass of the ripper; $m_{n}, m_{v}$, is the mass of the lower and upper longitudinal links of the 
hitch mechanism; $Q_{r}, Q_{v}$ are the horizontal and vertical components of the spring pressure force.

To the static equilibrium position

$$
\begin{gathered}
F_{y}=\Delta_{\mathrm{sT}} K_{z r} Z_{p} \\
R_{s}=0 \\
Q=Q_{0} ; \quad Q_{r}=Q_{0} \cos \alpha_{0} ; Q_{v}=Q_{0} \sin \alpha_{0} \\
\Delta R_{z}(t)=0 \\
\varphi=0
\end{gathered}
$$

where $\Delta_{\mathrm{ST}}$ is the vertical movement of the ripper under the action of its weight force and the pre-tension force of the spring; $K_{z r}$ is the number of ripper teeth; $Z_{p}$ is the coefficient of soil hardness related to one tooth; $Q_{0}$ is spring pre-tensioning force; $\alpha_{0}$ is the angle of inclination of the force vector to the horizon.

When the ripper deviates from the equilibrium position by an angle $\varphi$,

$$
\begin{gathered}
F_{y}=\left(\Delta_{\mathrm{sт}}+\ell_{p} \varphi\right) K_{z r} Z_{p} \\
R_{s}=\ell_{p} \varphi K_{z r} v_{p} \\
Q_{r}=\left\lfloor Q_{0}+Z \ell_{p}(1-\cos \varphi)\right] \cos \alpha \approx Q_{0} \cos \alpha \\
Q_{v}=\left\lfloor Q_{0}+Z \ell_{p} \sin \varphi\right\rfloor \sin \alpha \approx\left(Q_{0}-Z \ell_{p} \varphi\right) \sin \beta
\end{gathered}
$$

where $v_{p}$ is the coefficient of resistance (viscosity) of the soil, reduced to one tooth; $Z$ is the stiffness of the pressure spring. Substituting these values $F_{y}, R_{c}, Q_{r}$ and $Q_{v}$ and $Q_{v}$ in (4) and assuming that we have $\alpha \approx \alpha_{0}$

$$
\begin{aligned}
& J \frac{d^{2} \varphi}{d t^{2}}=\left(Q_{0} \cos \alpha_{0}-R_{x}\right) \ell_{p}+\left[m_{r}+0,5\left(m_{v}+m_{n}\right)\right] g \ell_{p}+\left(Q_{0}-Z \ell_{p} \varphi\right) \ell_{p} \\
& \sin \alpha_{0}-\left[\left(\Delta_{s t}+\ell_{p} \varphi\right) K_{z r} Z_{p}+K_{z r} v_{p} \ell_{p} \varphi+\Delta R_{z}(t)\right] \ell_{p}
\end{aligned}
$$

In the static equilibrium position

$$
\begin{aligned}
& {\left[m_{r}+0,5\left(m_{v}+m_{n}\right)\right] g \ell_{p}+Q_{c} \ell_{p} \sin \alpha_{0}-} \\
& -\Delta_{s t}+\ell_{p} R_{z r} Z_{p} \ell_{p}=0
\end{aligned}
$$

Taking this into account, the differential equation of the angular vibrations of the ripper is written as:

$$
\begin{aligned}
& J \frac{d^{2} \varphi}{d t^{2}}=v_{p} K_{z r} \cdot \ell_{p}^{2} \frac{d \varphi}{d t}+\left(R_{x}-Q_{0} \cos \alpha_{0}+\right. \\
& \left.+Z_{p} \ell_{p} \sin \alpha_{0}+Z_{p} K_{z r} \ell_{p}\right) \ell_{p} \varphi=-\Delta R_{z}(t) \ell_{p}
\end{aligned}
$$

Due to the variability of $R_{x}$, equation (16) is a linear inhomogeneous second-order differential equation with a variable coefficient. 
From the course of the theory of oscillations, it is known that in the system described by equation (16), theoretically, various parametric resonances are possible. However, numerous experimental studies conducted in laboratory and field conditions [10, 11] suggest that due to the large damping capacity of the soil, parametric fluctuations of the ripper are not observed. It performs forced oscillations under the action of the force $R_{z}(t)$. Therefore, in further studies, we will consider the force $\mathrm{Rx}$ to be a constant value equal to its average value.

Following the above, we consider the forced vibrations of the ripper.

Assuming that the disturbing force acting on the ripper changes according to the harmonic law, i.e.

$$
\Delta R_{z}(t)=\sum_{n=1}^{n_{1}} \Delta R_{p} \cos \left(n \omega t-\beta_{p}\right)
$$

where $\Delta R_{p}$ is the amplitude of the corresponding harmonic; $n=1,2 \ldots n_{1}$ is the number of harmonics ( $n_{1}$ is number of the last, achieve together), $\omega$ is the circular frequency change of the disturbing forces.

Substituting the value in equation $\Delta R_{p}(\mathrm{t})(16)$, we get:

$$
\begin{aligned}
& J \frac{d^{2} \varphi}{d t^{2}}+v_{p} K_{z r} \ell_{p}^{2} \frac{d \varphi}{d t}+\left(R_{x}-Q_{0} \cos \alpha_{0}+\right. \\
& \left.+Z_{p} K_{z r} \ell_{p}\right) \ell_{p} \varphi=-\left(\sum_{n=1}^{n_{1}} \Delta R_{p} \cos \left(n \omega t-\beta_{p}-\delta_{p}\right) \ell_{p}\right.
\end{aligned}
$$

Solving (18), we obtain the following equation, which determines the forced oscillations of the ripper

$$
\varphi(t)=\frac{\ell_{n}}{J} \sum_{n=1}^{n_{1}} \frac{\Delta R_{p} \cos \left(n \omega t-\beta_{p}-\delta_{p}\right)}{\sqrt{\left[\frac{\left(R_{x}-Q_{0} \cos \alpha_{0}+Z \ell_{p}+Z_{p} \ell_{p} K_{z r}\right) \ell_{p}}{J}-\left(n \omega^{2}\right)^{2}\right]+\frac{4 v_{p}^{2} K_{z r}^{2} \ell_{p}^{4}}{J^{2}}(n \omega)^{2}}}
$$

Where

$$
\begin{aligned}
& \beta_{p}=\operatorname{arctg} \frac{v_{p} K_{z r} \ell_{p}^{2} \omega}{\left(R_{x}-Q_{0} \cos \alpha_{0}+Z \ell_{p} \sin \alpha_{0}+Z_{p} K_{z r} \ell_{p}\right) \ell_{p}-J(n \omega)^{2}}-\text { phase shift } \\
& \mathrm{n}=1,2, \ldots \mathrm{n}
\end{aligned}
$$

From the analysis of the expression (19), it follows that the uniformity of the depth of the cultivator depends on the amplitude and frequency changes of the components of the disturbing force, physical and mechanical properties of the soil, the moment of inertia of the Ripper, the length of the longitudinal links parallelogram mechanism, the forces of the pre-tension pressure springs, and its stiffness.

According to the formula (19), the dependence of the change in the amplitude $A$ of the forced vibrations of the ripper on the stiffness and tension force of the spring (reloader) is 
constructed (Fig.2) $l_{p}=0.40 \mathrm{~m} ; n=1 ;=300 \mathrm{~N} ; \alpha_{0}=45^{\circ} ; K_{z r}=20 \mathrm{pcs} ; \omega=1 \mathrm{~S}-1 ; v_{p}=20 \cdot \mathrm{N} / \mathrm{cm}$; $\mathrm{J}=\mathrm{m}_{\mathrm{p}} \ell_{n}^{2} ; m_{p}=24 \mathrm{~kg} ; Z_{n}=4000 \mathrm{~N} / \mathrm{m} ; R_{x}=800 \mathrm{~N}[10]$.

As can be seen from Fig. 2, an increase in the stiffness of the pressure spring from 25 to $70 \mathrm{~N} / \mathrm{cm}$ leads to a decrease in the amplitude of the angular vibrations of the ripper, and consequently, an increase in

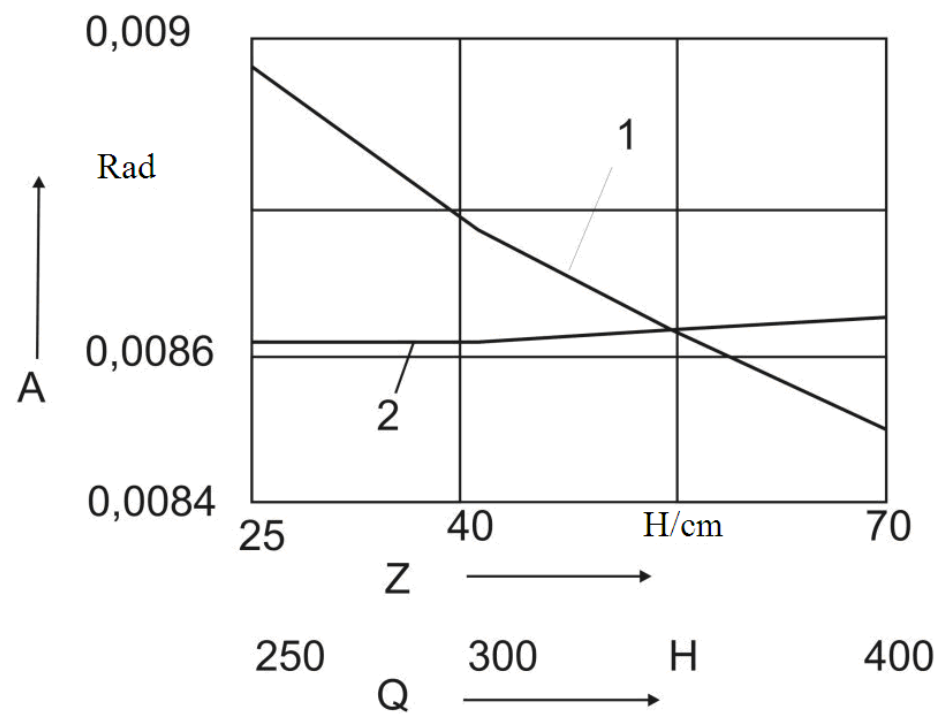

Fig. 2. Change in the amplitude $A$ of the angle of deviation $\varphi(t)$ of the longitudinal links of the parallelogram mechanism from the horizontal, depending on the stiffness $Z$ and the tension force $Q$ of the spring (reloader): $1-A=f(Z) ; 2-A=f(\mathrm{Q})$ uniformity of the depth of tillage. A change in the spring tension force from 250 to $400 \mathrm{~N}$ does not significantly affect these indicators.

\section{Conclusions}

1. A computational dynamic model is developed, and an equation describing the angular oscillations of the longitudinal links of the parallelogram ripper mechanism is obtained.

2. It is established that the required uniformity of the depth of tillage can be achieved by selecting the pre-tension force of the pressure spring and its rigidity.

3. Theoretical and experimental studies have established that the required uniformity of the processing depth with minimal energy consumption of the soil is provided with a pre-tension force of the pressure spring of the ripper attachment mechanism of $350 \mathrm{~N}$, spring stiffness of $40 \mathrm{~N} / \mathrm{cm}$, and a speed of $2.0 \mathrm{~m} / \mathrm{s}$.

\section{References}

1. Mamatov, F.M., Eshdavlatov, E., Suyunov, A. The Shape of the Mixing Chamber of the Continuous Mixer // Jour of Adv Research in Dynamical \& Control Systems, Vol. 12, 07-Special Issue, (2020). DOI: 10.5373/JARDCS/V12SP7/20202318 ISSN 1943$023 \mathrm{X}$.

2. Mamatov, F., Ergashev, I., Ochilov, S., Pardaev, X. Traction Resistance of Soil Submersibility Type "Paraplau" // Jour of Adv Research in Dynamical \& Control 
Systems, Vol.12, 07-Special Issue, (2020). DOI: 10.5373/JARDCS/V12SP7/20202336 ISSN1943-023X.

3. Aldoshin, N., Mamatov, F., Ismailov, I., Ergashov, G. Development of combined tillage tool for melon cultivation // 19th international scientific conference engineering for rural development Proceedings, Jelgava, 20.-22.05.2020. Volume 19. ISSN 16915976. DOI:10.22616/ERDev.2020.19.TF175.

4. Umurzakov, U., Mirzaev, B., Mamatov, F., Ravshanov, H., Kurbonov, S. A rationale of broach-plow's parameters of the ridge-stepped ploughing of slopes // XII International Scientific Conference on Agricultural Machinery Industry IOP Conf. Series: Earth and Environmental Science 403(2019) 012163 IOP Publishing doi:10.1088/1755-1315/403/1/012163.

5. Mirzaev, B., Mamatov, F., Chuyanov, D., Ravshanov, X., Shodmonov, G., Tavashov, R and Fayzullayev, X. Combined machine for preparing soil for cropping of melons and gourds // XII International Scientific Conference on Agricultural Machinery Industry. doi.org/10.1088/1755-1315/403/1/012158.

6. Mirzaev, B., Mamatov, F., Ergashev, I., Ravshanov, H., Mirzaxodjaev, Sh., Kurbanov, Sh., Kodirov, U and Ergashev, G. Effect of fragmentation and pacing at spot ploughing on dry soils // E3S Web of Conferences 97. doi.org/10.1051/e3sconf/201913501065.

7. Mamatov, F., Mirzaev, B., Shoumarova, M., Berdimuratov, P., Khodzhaev, D. Comb former parameters for a cotton seeder// International Journal of Engineering and Advanced Technology (IJEAT) Volume-9 Issue1 October/ DOI: 10.35940/ijeat.A2932.109119.

8. Mamatov, F., Mirzaev, B., Batirov, Z., Toshtemirov, S., Tursunov, O., Bobojonov, L. Justification of machine parameters for ridge forming with simultaneous application of fertilizers // CONMECHYDRO - 2020 IOP Conf. Series: Materials Science and Engineering 883(2020) 012165 IOP Publishing. doi:10.1088/1757899X/883/1/012165.

9. Mirzaev, B., Mamatov, F., Avazov, I., Mardonov, S. Technologies and technical means for anti-erosion differentiated soil treatment system // E3S Web of Conferences. doi.org/10.1051/e3sconf/20199705036.

10. Aldoshin, N., Didmanidze, O., Mirzayev, B., Mamatov, F. Harvesting of mixed crops by axial rotary combines // Proceeding of $7^{\text {th }}$ International Conference on Trends in Agricultural Engineering 2019. 17 $7^{\text {th }}-20^{\text {th }}$, Czech Republic. - pp.20-26. September (2019).

11. Mirzaev, B., Mamatov, F., Aldoshin, N and Amonov, M. Anti-erosion two-stage tillage by ripper// Proceeding of 7th International Conference on Trends in Agricultural Engineering 17th-20th. Czech Republic. - pp.391-396. September (2019).

12. Mirzaev, B., Mamatov, F., Ergashev, I., Islomov, Yo., Toshtemirov, B., Tursunov O. Restoring degraded rangelands in Uzbekistan // Procedia Environmental Science, № 6. - pp 395-404. (2019).

13. Uzakov, Z.U., Mamatov, F.M., Begulov, O. Implementation of object-oriented Programming technology in the one-dimensional oil displacement problem // International Conference on information Science and Communications Technologies: ICISCT 2019/0012008. Tashkent, Uzbekistan. INSPEC Accession Number: 19412491. DOI: 10.1109/ICISCT47635.2019.9012008.

14. Mamatov, F., Mirzaev, B., Berdimuratov, P., Turkmenov, Kh., Muratov, L., Eshchanova, G. The stability stroke of cotton seeder moulder // CONMECHYDRO 2020. IOP Conf. Series: Materials Science and Engineering 883 (2020) 012145 IOP Publishing. doi:10.1088/1757-899X/883/1/012145. 
15. Mamatov, F., Mirzaev, B., Tursunov, O. A Justification of Broach-Plow's Parameters of the Ridge-Stepped Ploughing // E3S Web of Conferences 97, 05035 (2019). doi.org/10.1051/e3sconf/20199705035.

16. Ahmedov, B.J., Mirzaev, B.S.,Mamatov, F.M., Khodzhaev, D.A., Julliev, M.K. Integrating of gis and gps for ionospheric perturbations in d- And f-layers using vlf receiver // InterCarto, InterGIS 26, - c. 547-560. DOI: 10.35595/2414-9179-2020-126-547-560.

17. Mamatov, F., Mirzaev, B., Tursunov, O., Ochilov, S and Chorieva, D. Relief, physicomechanical and technological properties of soil in the cotton growing area // ICECAE 2020. IOP Conf. Series: Earth and Environmental Science 614(2020) 012169. IOP Publishing. doi:10.1088/1755-1315/614/1/012169.

18. Shamsutdinov, Z., Ubaydullaev, Sh., Shamsutdinov, N., Mirzaev, B., Mamatov, F., and Chorshabiyev, N. The concept of the phytogenic field: theory, research experience and practical significance // ICECAE 2020. IOP Conf. Series: Earth and Environmental Science 614(2020) 012164. IOP Publishing. doi:10.1088/17551315/614/1/012164.

19. Umurzakov, U., Mamatov, F., Aldoshin, N., and Mirzaev, B. Exploration of tillage technologies in the Republic of Uzbekistan // ICECAE 2020 IOP Conf. Series: Earth and Environmental Science 614(2020) 012168. IOP Publishing. doi:10.1088/17551315/614/1/012168.

20. Mamatov, F., Aldoshin, N., Mirzaev, B., Ravshanov, H., Kurbanov, Sh and Rashidov, N. Development of a frontal plow for smooth, furless plowing with cutoffs // IPICSE 2020. IOP Conf. Series: Materials Science and Engineering 1030 (2021) 012135 IOP Publishing. doi:10.1088/1757-899X/1030/1/012135.

21. Mamatov, F., Mirzaev, B., Mirzahodzhaev, Sh., Uzakov, Z and Choriyeva, D. Development of a front plow with active and passive working bodies // IPICSE 2020. IOP Conf. Series: Materials Science and Engineering 1030 (2021) 012164. IOP Publishing. doi:10.1088/1757-899X/1030/1/012164.

22. Mamato, F.M., Eshdavlatov, E., Suyuno, A. Continuous Feed Mixer Performance //Journal of Advanced Research in Dynamical and Control Systems (JARDCS). Volume-12, 07-Spesia1 Issue, 2020. DOI: 10.5373/JARDCS/V12SP7/20202343. ISSN 1943-023X.

23. Mamatov, F., Ergashev, I., Mirzaev, B., Pardaev, X, Chorieva, D. Research of the Penetration Process of the Frontal Plow // 2nd Bukittinggi International Conference on Education (BICED) 2020. Journal of Physics: Conference Series 1779 (2021) 012002. IOP Publishing. doi:10.1088/1742-6596/1779/1/012002.

24. Kodirov, U., Aldoshin, N., Ubaydullayev, Sh., Sharipov, E., Muqimov, Z and Tulaganov, B. The soil preparation machine for seeding potatoes on comb // CONMECHYDRO - 2020 IOP Conf. Series: Materials Science and Engineering 883(2020) 012143 IOP Publishing doi:10.1088/1757-899X/883/1/012143.

25. Ravshanov, Kh., Fayzullaev, Kh., Ismoilov, I., Irgashev, D., Mamatov, S. The machine for the preparation of the soil in sowing of plow crops under film // CONMECHYDRO - 2020 IOP Conf. Series: Materials Science and Engineering 883(2020) 012138 IOP Publishing doi:10.1088/1757-899X/883/1/012138.

26. Ravshanov, H, Babajanov, L, Kuziev, Sh, Rashidov, N, Kurbanov, Sh. Plough hitch parameters for smooth tails// CONMECHYDRO - 2020 IOP Conf. Series: Materials Science and Engineering 883(2020) 012139 IOP Publishing doi:10.1088/1757899X/883/1/012139.

27. Chuyanov, D., Shodmonov, G.,Avazov, I., Rashidov, N, Ochilov, S. Soil preparation machine parameters for the cultivation of cucurbitaceous crops // CONMECHYDRO 
- 2020 IOP Conf. Series: Materials Science and Engineering 883(2020) 012139 IOP Publishing doi:10.1088/1757-899X/883/1/012122.

28. Mamatov F.M., Mirzaev B.S., Avazov I.Zh.. Agrotehnicheskie osnovy sozdanija protivojerozionnyh vlagosberegajushhih tehnicheskih sredstv obrabotki pochvy $\mathrm{v}$ uslovijah Uzbekistana // - Prirodoobustrojstvo, [In Russian]. (2014).

29. Mamatov F.M., Mirzaev B.S. Erosion preventive technology of crested ladder-shaped tillage and plow design // European Applied Sciences.- pp. 71-73. Stuttgart (Germany), (2014).

30. Lobachevskij Ja.P., Mamatov F., Jergashev I.T. Frontal'nyj plug dlja hlopkovodstva // - Hlopok, № 6. -pp. 35-37. [In Russian]. (1991).

31. Sokolov F.A. Agronomicheskie osnovy kompleksnoj mehanizacii hlopkovodstva. 224. [In Russian]. Tashkent, (1972).

32. Kurbanov Je.S. Vybor tipa i obosnovanie parametrov ryhlitelja navesnogo boronoval'nogo agregata dlja zony hlopkosejanija. Diss. ... kand. tehn. nauk.-Jangijul', -p. 163. [In Russian]. (1990).

33. Abdurahmonov U. N. "Dinamika dvizhenija ryhliteljaboronaval'nogo orudija". "Nauka, tehnika i obrazovanie". Rossija. [In Russian]. (2020).

34. Bajmetov R.I. Teoreticheskie osnovy i parametry orudija dlja obrabotki tjazhelyh glybistyh pochv $\mathrm{v}$ zone hlopkovodstva: Diss. ... kand. tehn. nauk.- 185 s. [In Russian]. -Tashkent, (1969).

35. Tuhtakuziev A. Sovershenstvovanie mehanizma naveski rabochih organov hlopkovyh kul'tivatorov //Sovershenstvovanie mashin i mehanizmov dlja hlopkovodstva.Sb.tr./SAIMJe. - S.83-87. [In Russian]. . -Tashkent, (1988)

36. Turanov H., Tuhtakuziev A., Kurbanov Je.S. Analiticheskaja mehanika ryhlitelja boronoval'nogo agregata //Izvestija AN UzSSR. - №1. - S.41-45. [In Russian]. (1991).

37. Bajmetov R.I., Tuhtakuziev A, Kurbanov Je.S. K obosnovaniju parametrov mehanizma naveski ryhlitelja boronoval'nogo agregata. //Mehanizacija hlopkovodstva- № 6,-S.3-4. [In Russian]. (1989).

38. Kurbanov Je.S. Vybor tipa i obosnovanie parametrov ryhlitelja navesnogo boronoval'nogo agregata dlja zony hlopkovdstva Avtoref.diss. . . .kand.tehn.nauk. Jangijul'. - 16. [In Russian]. (1990).

39. Batirov Z., Toirov I., Boymuratov F., Sharipov Sh. Layered application of mineral fertilizers with the coulter ripper of a combined unit//IOP Conf. Series: Materials Science and Engineering 1030 (2021).doi: 10.1088/1757-899X/1030/1/012168.

40. Batirov Z., Toirov I., Boymuratov F., Sharipov Sh. Layered application of mineral fertilizers with the coulter ripper of a combined unit//IOP Conf. Series: Materials Science and Engineering 1030 (2021). doi: 10.1088/1757-899X/1030/1/012168.

41. Mamatov F., Mirzaev B., Batirov Z., Toshtemirov S., Tursunov O., Bobojonov L. Justification of machine parameters for ridge forming with simultaneous application of fertilizers. //IOP Conf. Series: Materials Science and Engineering 883 (2020). IOP Publishing doi:10.1088/1757-899X/883/1/012165.

42. Mamatov, F., Mirzaev, B., Batirov, Z., Toshtemirov, S., Tursunov, O., Bobojonov, L. Justification of machine parameters for ridge forming with simultaneous application of fertilizers // CONMECHYDRO - 2020 IOP Conf. Series: Materials Science and Engineering 883(2020) 012165 IOP Publishing. doi:10.1088/1757899X/883/1/012165. 